\title{
Tools for discrimination and analysis of lake bacterioplankton subgroups measured by flow cytometry in a high-resolution depth profile
}

\author{
Stefan Andreatta1, Manfred M. Wallinger1, Jaume Piera ${ }^{2,3}$, Jordi Catalan², ${ }^{\text {, }}$ \\ Roland Psenner ${ }^{1}$, Julia S. Hofer ${ }^{1}$, Ruben Sommaruga ${ }^{1, *}$ \\ ${ }^{1}$ Institute of Zoology and Limnology, University of Innsbruck, Technikerstrasse 25, 6020 Innsbruck, Austria \\ ${ }^{2}$ Department of Ecology, University of Barcelona Diagonal 645, 08028 Barcelona, Spain \\ ${ }^{3}$ Present address: Department of Signal Theory and Communications, Escola Politécnica Superior de Castelldefels (EPSC), \\ Universitat Politécnica de Catalunya, Avenida Canal Olimpic s/n, 08860 Castelldefels, Barcelona, Spain \\ ${ }^{4}$ Present address: Limnology Unit (CSIC-UB), Centro de Estudios Avancados de Blanes (CEAB), Accés a la Cala St. \\ Francesc 14, 17300 Blanes, Spain
}

\begin{abstract}
A $24 \mathrm{~m}$ deep mesotrophic lake was sampled at $25 \mathrm{~cm}$ depth intervals throughout the whole water column for flow cytometric analysis of bacterioplankton, with the object of (1) assessing the suitability of image analysis algorithms to objectively discriminate bacterial subgroups in natural samples; (2) testing 2 models to evaluate the effect of changes in signal intensity versus changes in the relative abundance of the individual subgroups on bulk cell properties of the bacterial community; and (3) to examine the suitability of a numerical index for quantifying small-scale spatial variability in cell abundance. Within the heterotrophic bacterial community, 5 subgroups were detected by image analysis of DAPI fluorescence versus side scatter (SSC) histograms. On average for the whole profile, $91 \%$ (range: 86 to $94 \%$ ) of all measured bacteria belonged to the 5 subgroups. Along the depth profile, abundances within these subgroups showed trends which were different from that for the bacterial community as a whole. The comparison of the 2 numerical models suggested that shifts in average DAPI and SSC signals of the whole community are better explained by changes in relative abundance within individual subgroups rather than by signal shifts within individual subgroups. Spatial variability in cell abundance for most of the heterotrophic bacterioplankton subgroups was highest in the upper $4 \mathrm{~m}$ of the water column, corresponding to the zone of turbulent mixing, and between 9 and $12 \mathrm{~m}$, at the depth of maximum picocyanobacterial abundance. Our results show that flow cytometry in combination with image analysis of DAPI-SSC histograms at the level of bacterial subgroups allow objective assessment of the structure of the bacterial community and underpin potential sources of small-scale variability in bacterioplankton distribution.
\end{abstract}

KEY WORDS: Bacteria - Bacterial subgroups · Flow cytometry · Image analysis · Turbulence · Temperature microstructure $\cdot$ Lakes

\section{INTRODUCTION}

Depth profiles are among the most widely applied sampling strategies in studies of lake and ocean bacterioplankton. Conventionally, most investigations have explored bulk bacterial community properties at a spatial resolution of 1 to several meters (Pedrós-Alió \& Brock 1982, Cho \& Azam 1988, Dufour et al. 1990, Jellett et al. 1996). While Hutchinson (1961) assumed homogeneity at small scales, many researchers have since inferred the existence of significant heterogeneity at the millimeter and centimeter scale from theoretical consid- 
erations (Bell \& Mitchell 1972, Azam \& Ammerman 1984, Blackburn et al. 1997, Catalán 1999) or measured data (Børsheim et al. 1985, Mitchell \& Fuhrman 1989, Gasol et al. 1991, Duarte \& Vaqué 1992, Seymour et al. 2000). However, studies at the centimeter scale or below are still scarce, and high-frequency sampling is usually limited to only a small part of the water column. In contrast to microscopy-based studies, the use of flow cytometry has largely increased the capacity to analyze a high number of samples. However, a remaining problem is the use of proper analytical tools to extract, from a large amount of data, the information necessary to assess variability patterns for a certain parameter.

Recently, flow cytometry has been used to discriminate subgroups in bacterial assemblages based on their different nucleic acid contents (Li et al. 1995, Gasol et al. 1999, Servais et al. 2003). Bacterial subgroups of high nucleic acid content seems to account for most of the bacterial activity in a system as opposed to subgroups of low nucleic acid content, which are thus regarded as comprising mostly dead or dormant cells (Lebaron et al. 2001, 2002, Vaqué et al. 2001, Servais et al. 2003). Yet, the mechanism at the subgroup level that underlies changes in bulk bacterioplankton properties is uncertain. For example, an increase in the average DNA content of the bacterial assemblage could be explained by (1) an increase in DNA content (i.e. signal intensity) on a cellular basis including all or part of the bacteria, or (2) an increase in the relative abundance of DNA-rich cells, while the per cell content remains approximately constant.

In this study, we used a high-resolution depth profile of lake bacterioplankton measured by flow cytometry to (1) assess the suitability of image analysis algorithms previously tested in laboratory experiments (Andreatta et al. 2001) to objectively discriminate bacterial subgroups in natural samples, (2) test 2 models analyzing the effect of changes in signal intensity versus the effect of the relative abundance of the individual subgroups on bulk cell properties of the bacterial community, and (3) evaluate the suitability of an index allowing quantification of small-scale spatial variability in cell abundance in the water column. This numerical index was related to parameters measured at the same or higher spatial resolution, such as the physical microstructure of the water column and the abundance of picocyanobacteria.

\section{MATERIAL AND METHODS}

Sampling. The study site was Piburger See, a mesotrophic lake in the Tyrol, Austria $\left(45^{\circ} 11^{\prime} 30^{\prime \prime} \mathrm{N}\right.$, $\left.10^{\circ} 53^{\prime} \mathrm{E}\right)$, at $913 \mathrm{~m}$ above sea level. The general characteristics of the lake and background information on the microbial food web have been published elsewhere (Sommaruga \& Psenner 1995). All sampling and in situ measurements were done at the site of maximum depth $(24.7 \mathrm{~m})$ on June 23, 1999, during the summer stratification period. A total of 96 samples for bacterial analyses were taken at $25 \mathrm{~cm}$ depth intervals between 0 and $23.75 \mathrm{~m}$ using a flexible PVC tube (4 mm inner diameter) and $10 \mathrm{ml}$ syringes. To avoid tension on the tube, a weight (connected to a stainless steel cable marked at $25 \mathrm{~cm}$ intervals) was attached to the end of the tube. Before each sample was taken, a $50 \mathrm{ml}$ syringe was used to flush the tube with at least twice its complete volume. Finally, the samples were collected in $10 \mathrm{ml}$ sterile syringes. A Teflon valve was used to keep the end of the tube sealed while syringes were exchanged. Samples $(9.5 \mathrm{ml})$ were fixed by addition of formalin (1.8\% final concentration) and stored at $4^{\circ} \mathrm{C}$.

Flow cytometry. For flow cytometry analysis, $250 \mu \mathrm{l}$ of sample were stained with $10 \mu \mathrm{l} \mathrm{4} 4^{\prime}, 6^{\prime}$ diamidino2 phenylindole (DAPI) to a final concentration of $1 \mu \mathrm{mol}$ $\mathrm{l}^{-1}$. Fluorescent microspheres $(1 \mu \mathrm{m}$ TransFluoSpheres 488/560, Molecular Probes) were added at a final concentration of $4.3 \times 10^{5}$ as a counting and internal fluorescence reference. The absolute concentration of the stock solution of the microspheres was determined using a Coulter Counter (Coulter Multisizer II, Beckman Coulter). Flow cytometry analysis was performed with a MoFlo (DakoCytomation). The 2 lasers were water-cooled argon ion 4W Innova $90 \mathrm{C}+$ (Coherent) tuned to $350-365 \mathrm{~nm}$ at the first and $514 \mathrm{~nm}$ at the second observation point. Output power was $50 \mathrm{~mW}$ at TEM00 for both lasers. DAPI fluorescence from bacteria and yellow signals from the microspheres were measured from the first laser at 450/65 and 570/40 nm, respectively, and separated by a $525 \mathrm{~nm}$ longpass dichroic beamsplitter. Orthogonal side scatter (SSC, 514/10 nm) and chlorophyll autofluorescence (670/40 nm) were both measured from the second laser using a $555 \mathrm{~nm}$ longpass dichroic beamsplitter to divide the signal. The SSC signal was additionally filtered through an OD 1.3 neutral-density filter. Detectors were R-1477 photomultiplier tubes (Hamamatsu) at 550, 550, 600 and $750 \mathrm{~V}$ for DAPI, yellow, scatter, and chlorophyll signals, respectively. Measurements were triggered on logarithmically amplified DAPI or yellow signals using a logical OR on a custom multiple-trigger board (DakoCytomation). Between $4 \times 10^{4}$ and $5 \times 10^{4}$ bacteria were analyzed per sample.

Detection of bacterial subgroups. The detection of bacterial subgroups from cytograms essentially followed the procedure described in Andreatta et al. (2001). Manual gates were used to distinguish the bacterial community from background caused by microspheres, protozoan and algal cells, and from electronic 
noise. The distinctions were clear and identical gates were used for all samples. From the gated files, 5000 events from each sample were randomly selected and merged into a new flow-cytometry standard listfile to represent the whole series of measurements in 1 virtual sample, which was then used to calculate a bivariate histogram for SSC versus DAPI fluorescence $(512 \times 512$ channels). For image analysis, this bivariate histogram was transformed to a $512 \times 512$ pixel image, where gray values represented the number of events within each combination of channels. For subgroup detection, a top-hat filter (size 16 pixels, threshold 6) was applied followed by a $21 \times 21$ Gaussian kernel. Local maxima were then detected and clusters delimited by a watershed algorithm. Image analysis routines were programed and executed within Visilog 5.1 (Norpix), while FCS Flounder (Andreatta et al. 2001) was used to transfer data from flow cytometry standard (Dean et al. 1990) files to gray-scale images and tag events according to subgroups. Small peripheral groups of bacteria, which are too few to be identified as separate subgroups, can have a strong influence on another subgroup's statistics because of the logarithmic scale of the measurements. Thus, to concentrate on clearly defined clusters, only the area including the central $91 \%$ of the total bacterioplankton in the merged sample was attributed to subgroups. Data relating to all cells within this area were subsequently labeled 'all groups' in contrast to the 'total' heterotrophic bacterioplankton. Picocyanobacteria were clearly defined in the bivariate histograms and were thus manually gated.

Signal and abundance model. Absolute abundances of cells were calculated using the known concentration of microspheres that were added to each sample. Total bacterioplankton, bacterial subgroups, and picocyanobacteria were characterized by their abundance and mean DAPI and SSC signals, as well as mean chlorophyll autofluorescence for picocyanobacteria. Although it is difficult to translate flow cytometry signals quantitatively to cellular properties, there is generally a robust positive correlation between DAPI fluorescence and DNA content (Loferer-Krößbacher et al. 1999, Button \& Robertson 2000, Gasol \& Del Giorgio 2000) and between SSC and cell size (Servais et al. 1999).

The average values of properties for all cells found within subgroups are equivalent to the average of all individual subgroup means weighted by the abundance within each subgroup as shown in Eq. (1):

$$
a_{i}=\sum_{j=1}^{g} a_{i j} \times \frac{n_{i j}}{n_{i}}
$$

where $a_{i}$ is the weighted average of a parameter for all cells in all subgroups within Sample $i$ (community average), $g$ is the number of subgroups, $a_{i j}$ is the average of the parameter in Subgroup $j, n_{i j}$ is the abun- dance of cells in Subgroup $j$, and $n_{i}$ is the abundance of cells in all subgroups in Sample $i$. Changes of this community mean can thus be attributed to shifts of average signals or relative abundance within subgroups. To distinguish between abundance and signal (i.e. SSC or DAPI) effects, we calculated 2 models and compared them to the 'all groups' average.

The 'signal model' was used to show the influence of changes in the average signal within individual subgroups over the series of samples. Following Eq. (2):

$$
a_{i}^{s_{i}}=\sum_{j=1}^{g}\left[a_{i j} \times \frac{1}{S} \times \sum_{k=1}^{s}\left(\frac{n_{j k}}{n_{k}}\right)\right]
$$

a weighted average $\left(a_{i}^{s}\right)$ of mean signals was calculated for each Sample $i$, but the weight for each subgroup was set to the average relative abundance over the whole sample series; $g$ is the number of subgroups, $a_{i j}$ is the average of the parameter in Subgroup $j, s$ is the number of samples within the series, $n_{j k}$ is the abundance of cells in Subgroup $j_{1}$, and $n_{k}$ is the abundance of cells in all groups in Sample $k$.

In contrast, the 'abundance model' revealed the importance of changes in the relative abundance within subgroups over the series. As described by Eq. (3):

$$
a_{i}^{a}=\sum_{j=1}^{g}\left(\frac{1}{s} \times \sum_{k=1}^{s} a_{j k} \times \frac{n_{i j}}{n_{i}}\right)
$$

a weighted average $\left(a^{a}{ }_{i}\right)$ was calculated for each Sample $i$, where $g$ is the number of subgroups, $s$ is the number of samples within the series, $a_{j k}$ is the average of the parameter in Subgroup $j$ in Sample $k, n_{i j}$ is the abundance of cells in Subgroup $j$, and $n_{i}$ is the abundance of cells in all subgroups in Sample $i$. Average signal values were in this case set to the average value for the whole series, while the relative abundances were calculated for each sample.

To compare the influence of within-group signal shifts versus relative abundance changes on the average of all cells, regressions of this community average over the signal model and the abundance model were calculated. Thus, the coefficient of determination $\left(\mathrm{R}^{2}\right)$ estimated the amount of variability of the community average explained by each model, while intercept and slope indicated how close the models came to reproduce the actual values. A different approach employed the average residual of the community average that was not explained by each model. The mean relative residual was calculated for each model according to Eq. (4):

$$
r=\sum_{i=1}^{s}\left|\frac{a_{i}^{m_{i}}}{a_{i}}-1\right|
$$


where $r$ is the average residual value calculated for a series of $s$ samples, $a^{m}{ }_{i}$ is the model average for Sample $i$ equal to $a^{s}{ }_{i}$ (Eq. 2) or $a^{a}{ }_{i}$ (Eq. 3), and $a_{i}$ is the community average for Sample $i$ (Eq. 1).

Variability index. Small-scale variations in cell abundance for 'all groups' and the different subgroups of heterotrophic bacteria in the water column were estimated by a numerical indicator according to Eq. (5):

$$
v_{i}=\left(\sum_{j=i-1}^{i+1}\left|n_{j}-n_{j+1}\right|\right)-\left|n_{i-1}-n_{i+2}\right|
$$

where $V_{i}$ is the variability index calculated for the $i$ th element in a series of measurements and $n$ is the abundance. This index corresponds to the sum of the absolute differences between several consecutive values minus the absolute difference between the first and the last of the values within the chosen range. Therefore, the calculated parameter is high for zigzag lines and zero for monotonic changes, even at steep gradients. The number of values used in each calculation determines the spatial range at which variations are investigated. In this study, we chose a range of 4 values, corresponding to a $75 \mathrm{~cm}$ depth difference.

Water-column microstructure and oxygen measurements. The physical microstructure of the water column was determined with a profiler equipped with fast-response sensors for measuring temperature (FP07 thermistor) conductivity (PME 4-electrode), and pressure (Keller PSI PAA-10 sensor). The profiler rises vertically at $10 \mathrm{~cm} \mathrm{~s}^{-1}$, sampling at $100 \mathrm{~Hz}$ to obtain a spatial resolution of ca. $1 \mathrm{~mm}$. We obtained 12 temperature profiles, from which Thorpe displacements $(d T)$ were calculated (Thorpe 1977). In the case of low-conductivity waters, where salinity does not play any significant role in density fluctuations, Thorpe displacements are usually computed by comparing the measured tempera-

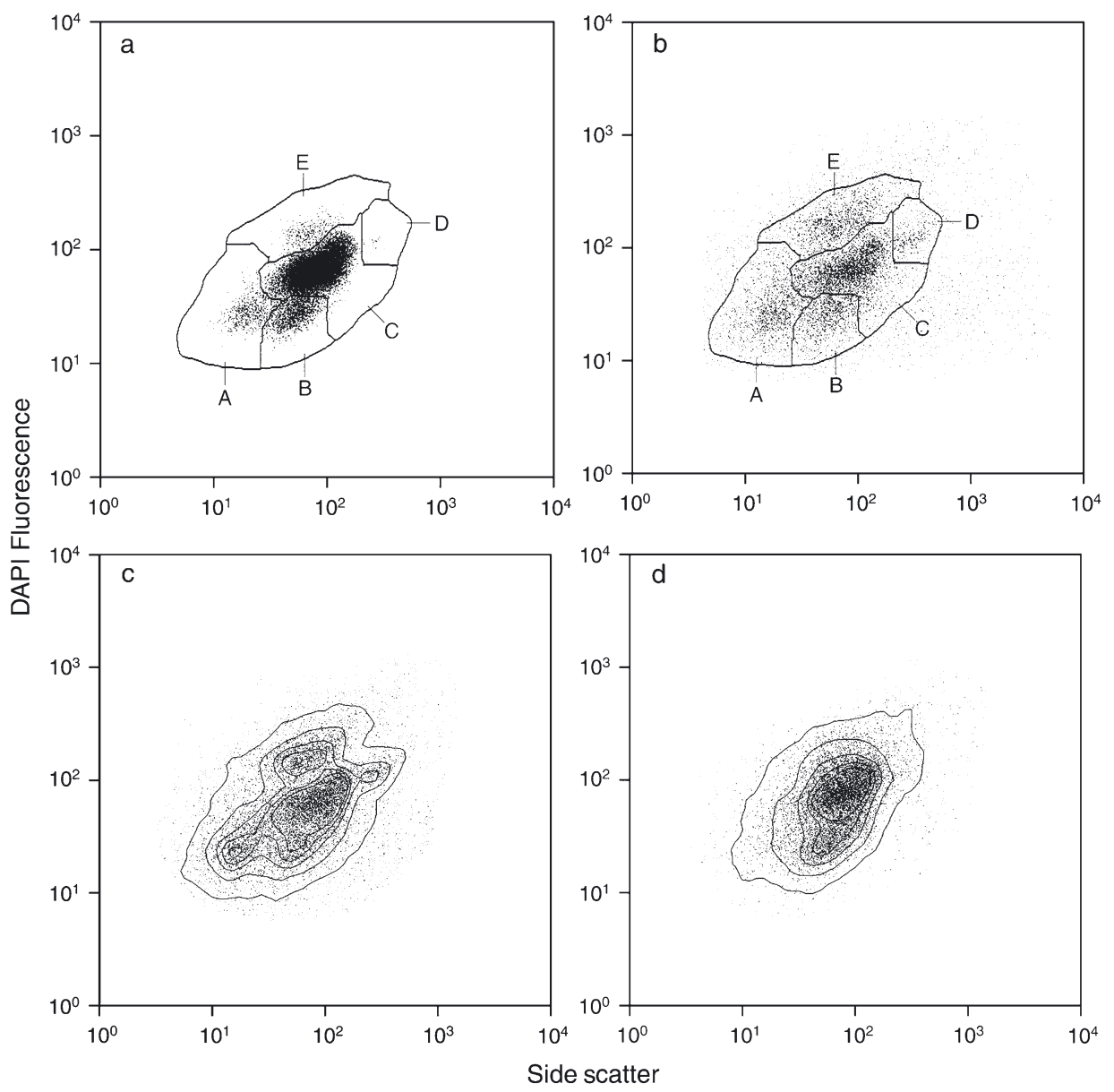

Fig. 1. DAPI fluorescence versus side scatter cytograms of (a) a virtual merged sample (obtained from random subsampling of 5000 events from each of 96 samples in vertical profile), used to discriminate Subgroups A to E by image analysis; (b) $10 \mathrm{~m}$ depth sample, showing an example of the most common cytometry pattern observed in profile with overlay of subgroup borders extracted from virtual merged sample; (c) same sample as in (b) but with isolines showing agreement between original data and definition of subgroups; (d) $20 \mathrm{~m}$ depth sample, showing disagreement with general pattern: here, presence of Subgroups A, D and $\mathrm{E}$ is too weak to be detectable 
ture profile $T(z)$ with a monotonic reference profile $T_{\mathrm{m}}(z)$ obtained by reordering $T(z)$ to make the profile gravitationally stable. For each measured depth $z_{i}$ a Thorpe displacement is then computed as the difference between the depth of the sample in the original profile $T\left(z_{i}\right)$ and the depth of the sample with the same temperature in the reference profile, i.e. $d T\left(z_{i}\right)=z_{i}-z_{j}$, for $T\left(z_{i}\right)=T_{\mathrm{m}}\left(z_{j}\right)$. The measured temperature profiles were analyzed following the method proposed by Piera et al. (2002), which uses 2 algorithms. The first algorithm is based on a wavelet denoising procedure, which rejects most of the noise present in the measured profiles; the second is based on a semi-quantitative analysis of the Thorpe displacements that compares each displacement $d T$ with its potential error $\mathrm{E}_{d T}$ to classify the samples into 3 state classes: zero $(d T=0)$, uncertain $\left(d T<\mathrm{E}_{d T}\right)$, and validated $\left(d T>\mathrm{E}_{d T}\right)$. This classification allows the computation of distinct indices that consider the $d T$ statistics in segments of $\mathrm{N}$ points. The displacement index, $I_{\mathrm{D}(\mathrm{N})}$, reflects the proportion of validated values, whereas the change index, $I_{\mathrm{C}(\mathrm{N})}$ refers to the percentage of consecutive validated $d T$ values with opposite signs. In the present study, the number of averaging points was set to $\mathrm{N}=50$ because this provides statistical robustness while maintaining a high vertical resolution $(5 \mathrm{~cm})$. The turbulent regions were finally identified by high $I_{\mathrm{D}(50)}$ and $I_{\mathrm{C}(50)}$ values. Finally, measurements of oxygen concentration in the water column were done at 9 discrete depths using the standard Winkler method.

\section{RESULTS AND DISCUSSION}

The results of the image analysis of a virtual merged sample representing the entire series of 96 individual samples discriminated 5 subgroups (Fig. 1a). Upon visual inspection, these borders showed good fit to the clusters within individual samples along most of the vertical profile (Fig. 1b,c). Only occasionally did cytograms of DAPI versus SCC show disagreement with the borders established for the virtual merged sample (Fig. 1d). Samples from the deepest $2 \mathrm{~m}$ included dispersed cells of very high SSC that could not be discriminated as a distinct subgroup by our approach (data not shown). Over the whole series, between 86 and $94 \%$ (average $91 \%$ ) of all measured bacteria belonged to the discriminated subgroups. These cells were representative of the total bacterioplankton in terms of abundance (Fig. 2: left), DAPI and SSC signals (data not shown). The central Subgroup C contained most bacteria in each sample and its contribution to the 'all-groups' abundance showed a clear increase with increasing depth (Fig. 2: right). Subgroups A and B, representing bacteria with low DAPI fluorescence and low-to-medium SSC, were more abundant in the uppermost layers. Subgroups D and E, on the other hand, showed relatively high DAPI signals and high and medium SSC, respectively. In contrast to Subgroup D, which showed a rather uniform distribution throughout the water column, the relative contribution of Subgroup E to the abundance of all groups increased between 4 and $19 \mathrm{~m}$ depth.

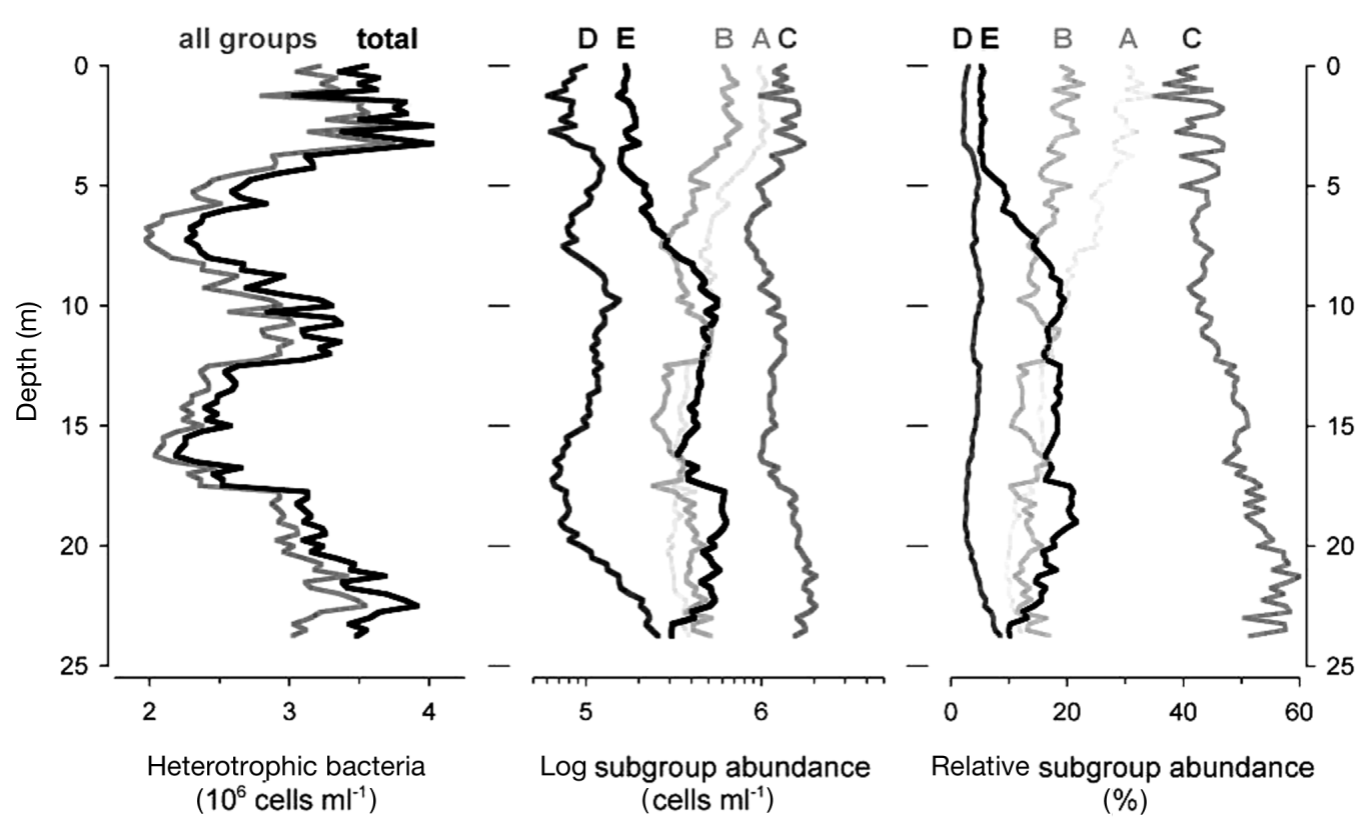

Fig. 2. Absolute abundance of heterotrophic bacterioplankton for all 5 subgroups (A to E) combined and total heterotrophic bacterioplankton (left), absolute subgroup abundance shown as logarithms (center), and relative abundances of subgroups as percent of 'all groups' abundance (right) 
Table 1. Regressions of DAPI fluorescence and side scatter community averages on signal and abundance models and the average relative residual of community average not explained by each model. $\mathrm{R}^{2}$ : coefficient of determination. See 'Materials and methods' for explanation on models

\begin{tabular}{|lcccc|}
\hline $\begin{array}{l}\text { Parameter } \\
\text { Model }\end{array}$ & $\mathrm{R}^{2}$ & $\begin{array}{c}\text { Regression } \\
\text { intercept }\end{array}$ & Slope & $\begin{array}{c}\text { Residual } \\
(\%)\end{array}$ \\
\hline DAPI fluorescence & & & & \\
$\quad$ Signal & 0.94 & -166.0 & 3.03 & 11.8 \\
$\quad$ Abundance & 0.99 & -25.7 & 1.36 & 4.6 \\
Side scatter & & & & \\
$\quad$ Signal & 0.20 & -38.8 & 1.48 & 7.3 \\
$\quad$ Abundance & 0.91 & -5.5 & 1.07 & 2.7 \\
\hline
\end{tabular}

The total abundance of bacterioplankton varied between 2.2 and $4.0 \times 10^{6}$ cells ml $^{-1}$ (Fig. 2). Zones of high bacterial abundance were found between 0 and $4 \mathrm{~m}$ depth, around $11 \mathrm{~m}$, and below $17 \mathrm{~m}$. The pattern of total abundance was closely related to the abundance of Subgroup C $(\mathrm{R}=0.82, \mathrm{p}<0.001)$. Other subgroups showed completely different trends for some parts of the depth profile (Fig. 2: center).

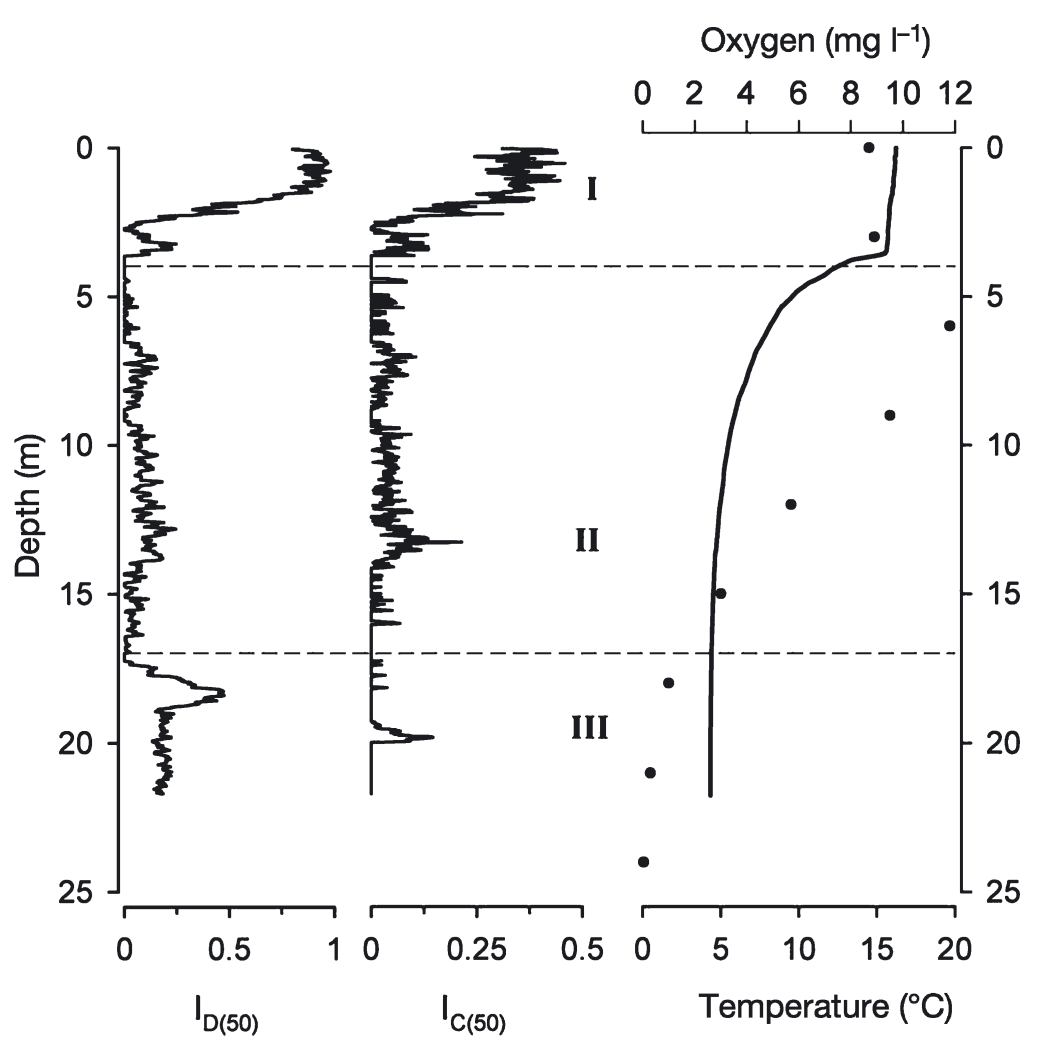

Fig. 3. Profiles of averaged index displacement, $I_{\mathrm{D}(50)}$ (left) and averaged index change, $I_{C(50)}$ (center). Right-hand curve: temperature profile at 13:00 h on June 23, 1999; $(\bullet)$ oxygen concentration in water column. Horizontal dashed lines (I to III): 3 zones of different turbulence regimes
The signal model (Eq. 2) and abundance model (Eq. 3) were used to analyze DAPI fluorescence and SSC patterns. Thus, it was possible to estimate the influence of average signal and relative abundance within subgroups from the community average (Eq. 1), comprising all 5 subgroups. To describe this relation, regressions over each model were calculated for DAPI and SSC community average and the average relative residuals were determined (Eq. 4, Table 1). For both DAPI and SSC signals, average residuals were approximately 2.5 times higher for the signal model than for the abundance model. Furthermore, the abundance model regressions exhibited slopes closer to 1 , offsets closer to 0 , and higher $\mathrm{R}^{2}$ suggesting that changes in bulk community properties were predominantly caused by changes in abundance of the relative subgroups rather than by changes in the signal intensity of single cells.

Based on the computation of Thorpe displacements, 3 zones of different turbulence regimes were revealed (Fig. 3). Zone I: high $I_{\mathrm{C}(50)}$ and $I_{\mathrm{D}(50)}$ values marked a turbulent region extending from the surface to $4 \mathrm{~m}$ depth, which was also the depth of the seasonal thermocline; within this zone, maximum turbulence was found between $0 \mathrm{~m}$ and the diurnal thermocline at $2 \mathrm{~m}$ depth. Zone II: moderate-to-low turbulence was observed between 4 and $17 \mathrm{~m}$ depth. Zone III: below $17 \mathrm{~m}$ depth $I_{\mathrm{D}(50)}$ increased again, while $I_{\mathrm{C}(50)}$ remained low; this zone was also characterized by low oxygen values (<1 $\mathrm{mg} \mathrm{l}^{-1}$, Fig. 3)

Small-scale variations in the abundance of all groups and of the 5 subgroups of heterotrophic bacteria were estimated by the index described by Eq. (5) (Fig. 4). The spatial resolution of sampling $(25 \mathrm{~cm})$ was adequate to detect zones of elevated variability that extended over a few meters. The variability index for the 'all groups' abundance (Fig. 4a) was high in the epilimnion between 0 and $4 \mathrm{~m}$ depth, where turbulent mixing was observed (Zone $\mathrm{I}_{\text {; }}$ Fig. 3), and between 9 and $12 \mathrm{~m}$, corresponding to the zone of maximum picocyanobacterial abundance (Fig. 4g). This pattern was usually reflected in the variability index for Subgroups A, B and C (Fig. 4b-d) and partially for Subgroup E, which did not show variability in Zone I (Fig. 4f). In contrast, Subgroup D showed the lowest variability along the water column (Fig. 4e). Correlations between turbulence indices and variability of abundance, including picocyanobacteria, for the whole 


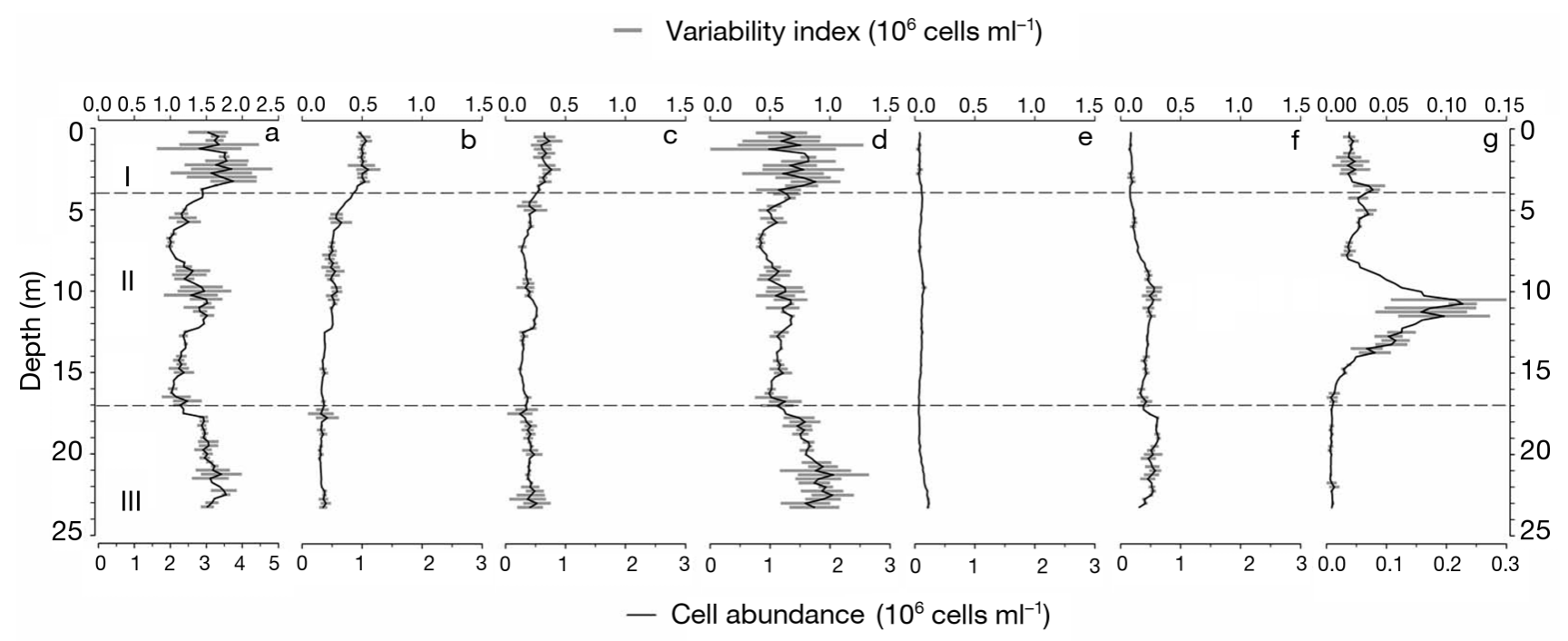

Fig. 4. Variability index (horizontal gray bars) for (a) all subgroups combined, (b-f) Subgroups A to E, and (g) picocyanobacteria; abundance of respective groups (lines) is included for comparison. Note 3 different scales on $x$-axis for (a), (b-f) and (g). Horizontal dashed lines indicate 3 zones of different turbulence (I to III) as in Fig. 3

water column were loose $(\mathrm{R} \leq 0.42)$ and normalization of the variability index through division by total abundance did not alter the observed trends.

The applied procedure for bacterial subgroup detection, which was previously tested in a chemostat experiment (Andreatta et al. 2001), performed well in our high-resolution depth profile. Although small and dispersed groups (which were present in only a small fraction of the samples) were not discriminated and thus excluded from the analysis, they could easily be detected by superimposing the cytogram from the particular depth over that of the general merged file. Thus, the main advantage of this procedure lies in the possibility of separating bacterial subgroups according to an objective criterion that can subsequently be subjected to rigorous comparative analysis.

A clear separation into only 2 groups of cells, i.e. those with high and low DNA content, was in most cases not apparent in our samples, but cytograms showed a more complex heterogeneity of bacterioplankton (Fig. 1) as has also been found by other investigators (Li et al. 1995, Troussellier et al. 1999). At present we do not know the ecological significance or taxonomical affiliation of the individual subgroups, but interestingly they were always present along the water column although their abundance varied significantly (Fig. 2). Thus, together they represented a much more detailed picture than that provided by analysis of total bacterial numbers alone. For example, the abundance of total bacteria was similar at 3 and $12 \mathrm{~m}$ depths, while the proportion of individual subgroups was markedly different between these 2 depths (Fig. 2). Evidently, total abundance is most strongly influenced by domi- nating groups, whereas trends of less abundant subgroups may be completely masked. Consequently, total bacterial abundance, while being an important parameter in many aspects, does not give adequate information about similarity between samples, and may in many cases reflect changes in bacterioplankton only weakly.

Measurements of DNA content and cell size reflected the mechanism of changes in cellular properties within the bacterial community. Changes of these properties at the community level were mainly caused by changes in relative abundance of subgroups rather than by shifts in average values within individual subgroups. These findings are consistent with laboratory studies with a mixed bacterial community (Andreatta et al. 2001). Further investigations of this phenomenon in both spatial and temporal series of samples from different systems could reveal whether this mechanism is universal for bacterioplankton or depends on specific environmental conditions.

A question that cannot be answered from our data alone is whether the observed increase in abundance in individual subgroups was due to replication within these groups, or if cells frequently change between groups during their life cycle. However, the relatively clear and stable division between the groups in the SSC versus DAPI distributions did not suggest very frequent changes. This supports the idea that bacterial subgroups detected by flow cytometry represent taxonomic entities (Bernard et al. 2000, Zubkov et al. 2002) or distinct physiological states (Gasol et al. 1999).

Information on the effects of turbulence on bacteria has mostly been derived from laboratory experiments 
(Peters et al. 1998, Sieracki et al. 1999) and only a few field studies (Moeseneder \& Herndl 1995). Modern physical probes, however, allow the study in situ of the effect of turbulences at very small scales (Imberger 1994), and flow cytometry supplements these measurements with high-resolution biological data. The variability index used in our study proved to be sufficiently sensitive to detect zones of significant smallscale spatial variations in bacterial abundance. Between 0 and $4 \mathrm{~m}$ depth, this variability was closely related to turbulent mixing (Fig. 3) which, probably by destroying existing gradients of bacterial abundance, increased the heterogeneity of cell distribution (Abraham 1998). Below this upper zone dominated by turbulence, a second zone of high variability around $11 \mathrm{~m}$ corresponded conspicuously with the maximum numbers of picocyanobacteria. The sharp increase and decrease in picocyanobacterial abundance and consequently the high variability index for that zone (Fig. 4g) may represent a natural gradient for the bacterial community. In fact, turbulent transport was too low to disturb such a gradient in this layer (Fig. 3). Thus, the observed high sample-to-sample variations were more probably due to an aggregated bacterial distribution (Duarte \& Vaqué 1992), as observed in very active zones (Blackburn et al. 1997). Regarding Zone III (Fig. 3), it is remarkable that the sharp increase in bacterial abundance below $17 \mathrm{~m}$ depth corresponded very closely with the upper limit of that layer and the increase in $I_{\mathrm{D}(50)}$. However, the low $I_{\mathrm{C}(50)}$ values suggest either a turbulent bottom-boundary layer (Imberger 1994, Lerman et al. 1995), or convective turbulences from a slightly warmer sediment, which might also explain the increase in the variability index for bacterial abundance in that zone (Fig. 4). Zone III was also characterized by an increase in relative abundance of a high SSC subgroup (D, Fig. 2) particularly below $20 \mathrm{~m}$, and by a dispersed group of very large cells in the lowest $2 \mathrm{~m}$ of the profile, where anoxic conditions prevailed (Fig. 3). This corresponds to results for other anoxic lakes, where an increase in bacterial abundance and cell size has been documented (Cole et al. 1993).

In conclusion, the combination of high-resolution sampling and analysis at the level of bacterial subgroups in this study produced a very detailed image of the bacterioplankton assemblage. The detection of subgroups helped to identify different trends in the bacterial community over the depth profile and enabled us to elucidate the mechanisms of changes in bulk community properties. The finely resolved sampling and the use of the variability index, on the other hand, made it possible to investigate small-scale variations in bacterial abundance in connection with turbulence and the distribution of cyanobacteria in the water column. For future investigations, it will be particularly interesting to combine this approach with high-resolution analyses of physical, chemical and activity parameters, as well as with a taxonomic characterization of the different subgroups.

Acknowledgements. This work was supported by the Austrian Science Foundation through grants P-12718-BIO and P-14387-BIO. Participation of J.C. and J.P. was made possible through the collaborative scientific program between Austria and Spain (Grant ÖAD \#17/2002).

\section{LITERATURE CITED}

Abraham ED (1998) The generation of plankton patchiness by turbulent stirring. Nature 391:577-580

Andreatta S, Wallinger MM, Posch T, Psenner R (2001) Detection of subgroups from flow cytometry measurements of heterotrophic bacterioplankton by image analysis. Cytometry 44:218-225

Azam F, Ammerman JW (1984) Cycling of organic matter by bacterioplankton in pelagic marine ecosystems: microenvironmental considerations. In: Fasham MJR (ed) Flows of energy and materials in marine ecosystems. Plenum Press, New York, p 345-360

Bell W, Mitchell R (1972) Chemotactic and growth responses of marine bacteria to algal extracellular products. Biol Bull (Woods Hole) 143:265-277

Bernard L, Courties C, Servais P, Troussellier M, Petit M, Lebaron P (2000) Relationships among bacterial cell size, productivity, and genetic diversity in aquatic environments using cell sorting and flow cytometry. Microb Ecol 40:148-158

Blackburn N, Azam F, Hagström Å (1997) Spatially explicit simulations of a microbial food web. Limnol Oceanogr 42: 613-622

Børsheim KY, Kuenen JG, Gottschalk J, Dundas I (1985) Microbial activities and chemical gradients in the chemocline of a meromictic lake in relation to the precision of the sampling procedure. FEMS Microbiol Ecol 31:337-341

Button DK, Robertson B (2000) Effect of nutrient kinetics and cytoarchitecture on bacterioplankter size. Limnol Oceanogr 45:499-505

Catalan J (1999) Small-scale hydrodynamics as a framework for plankton evolution. Jpn J Limnol 60:469-494

Cho BC, Azam F (1988) Major role of bacteria in biogeochemical fluxes in the ocean's interior. Nature 332:441-443

Cole JJ, Pace ML, Caraco NF, Steinhart GS (1993) Bacterial biomass and cell size distributions in lakes: more and larger cells in anoxic waters. Limnol Oceanogr 38: $1627-1632$

Dean PN, Bagwell CB, Lindmo T, Murphy RF, Salzman GC (1990) Data file standard for flow cytometry. Cytometry 11: 323-332

Duarte CM, Vaqué D (1992) Scale dependence of bacterioplankton patchiness. Mar Ecol Prog Ser 84:95-100

Dufour P, Torreton JP, Colon M (1990) Advantages of distinguishing the active fraction in bacterioplankton assemblages: some examples. Hydrobiologia 207:295-301

Gasol JM, Del Giorgio PA (2000) Using flow cytometry for counting natural planktonic bacteria and understanding the structure of planktonic bacterial communities. Sci Mar 64:197-224

Gasol JM, Garcia-Cantizano J, Massana R, Peters F, Guerrero 
R, Pedrós-Alió C (1991) Diel changes in the microstratification of the metalimnetic community in Lake Cisó. Hydrobiologia 211:227-240

Gasol JM, Zweifel UL, Peters F, Fuhrman JA, Hagström $\AA$ (1999) Significance of size and nucleic acid content heterogeneity as measured by flow cytometry in natural planktonic bacteria. Appl Environ Microbiol 65:4475-4483

Hutchinson GE (1961) The paradox of the plankton. Am Nat 95:137-141

Imberger J (1994) Transport processes in lakes: a review. In: Margalef R (ed) Limnology now: a paradigm of planetary problems. Elsevier, Amsterdam

Jellett JF, Li WKW, Dickie PM, Boraie A, Kepkay PE (1996) Metabolic activity of bacterioplankton communities assessed by flow cytometry and single carbon substrate utilization. Mar Ecol Prog Ser 136:213-225

Lebaron P, Servais P, Agogue H, Courties C, Joux F (2001) Does the high nucleic acid content of individual bacterial cells allow us to discriminate between active cells and inactive cells in aquatic systems? Appl Environ Microbiol 67:1775-1782

Lebaron P, Servais P, Baudoux AC, Bourrain M, Courties C, Parthuisot N (2002) Variations of bacterial-specific activity with cell size and nucleic acid content assessed by flow cytometry. Aquat Microb Ecol 28:131-140

Lerman A, Imboden D, Gat J (1995) Physics and chemistry of lakes. Springer-Verlag, Berlin

Li WKW, Jellett JF, Dickie PM (1995) DNA distributions in planktonic bacteria stained with TOTO or TO-PRO. Limnol Oceanogr 40:1485-1495

Loferer-Krößbacher M, Witzel KP, Psenner R (1999) DNA content of aquatic bacteria measured by densitometric image analysis. Ergeb Limnol 54:185-198

Mitchell JG, Fuhrman JA (1989) Centimeter scale vertical heterogeneity in bacteria and chlorophyll a. Mar Ecol Prog Ser 54:141-148

Moeseneder MM, Herndl GJ (1995) Influence of turbulence on bacterial production in the sea. Limnol Oceanogr 40: 1466-1473

Pedrós-Alió C, Brock TD (1982) Assessing biomass and production of bacteria in eutrophic Lake Mendota, Wisconsin.

Editorial responsibility: John Dolan,

Villefranche-sur-Mer, France
Appl Environ Microbiol 44:203-218

Peters F, Marrasé C, Gasol JM, Sala MM, Arin L (1998) Effects of turbulence on bacterial growth mediated through food web interactions. Mar Ecol Prog Ser 172:293-303

Piera J, Roget E, Catalan J (2002) Turbulent patch identification in microstructure profiles: a method based on wavelet denoising and Thorpe displacement analysis. J Atmos Ocean Technol 19:1390-1402

Servais P, Courties C, Lebaron P, Troussellier M (1999) Coupling bacterial activity measurements with cell sorting by flow cytometry. Microb Ecol 38:180-189

Servais P, Casamayor EO, Courties C, Catala P, Parthuisot N, Lebaron P (2003) Activity and diversity of bacterial cells with high and low nucleic acid content. Aquat Microb Ecol 33:41-51

Seymour JR, Mitchell JG, Pearson L, Waters RL (2000) Heterogeneity in bacterioplankton abundance from 4.5 millimetre resolution sampling. Aquat Microb Ecol 22: 143-153

Sieracki ME, Cucci TL, Nicinski J (1999) Flow cytometry analysis of 5-cyano-2,3-ditolyl tetrazolium chloride activity of marine bacterioplankton in dilution cultures. Appl Environ Microbiol 65:2409-2417

Sommaruga R, Psenner R (1995) Trophic interactions within the microbial food web in Piburger See (Austria). Arch Hydrobiol 132:257-278

Thorpe SA (1977) Turbulence and mixing in a Scottish loch. Philos Trans Soc Lond A 286:125-181

Troussellier M, Courties C, Lebaron P, Servais P (1999) Flow cytometry discrimination of bacterial populations in seawater based on SYTO 13 staining of nucleic acids. FEMS Microbiol Ecol 29:319-330

Vaqué D, Casamayor EO, Gasol JM (2001) Dynamics of whole community bacterial production and grazing losses in seawater incubations as related to the changes in the proportions of bacteria with different DNA content. Aquat Microb Ecol 25:163-177

Zubkov MV, Fuchs BM, Tarran GA, Burkill PH, Amann R (2002) Mesoscale distribution of dominant bacterioplankton groups in the northern North Sea in early summer. Aquat Microb Ecol 29:135-144

Submitted: November 20, 2003; Accepted: March 19, 2004 Proofs received from author(s): June 29, 2004 